\title{
Easy and Inexpensive Display Ideas for the Small Library
}

\author{
Anne Sanders
}

During the past thirteen years, I have made many posters, signs, brochures, flyers, and pamphlets for the libraries and bookmobiles in a fourcounty regional public library sysem. Two of the libraries have glass-enclosed display cases at each end of the circulation desk. I have prepared monthly exhibits in those cases for eight years. With meager funds, the task has been a real challenge, and it is with this in mind that I have written this article. By seeking alternatives to spending money, librarians with small budgets can provide attractive and fresh displays.

This article is for persons with little or no training in graphics and design. It is not intended as a blueprint for making displays but as a stimulus for the creative worker.

\section{Some Basic Tips}

Be ever on the lookout for ideas. As you shop or browse for yourself, notice the decorations and promotional items around you. Learn to look carefully through magazines and newspapers for "catchy" captions, phrases, words, and pictures for clip art. Look on every experience as an opportunity to get an idea. Just taking a walk can sometimes bring to mind a way to use leaves, shells, and other such items.

Learn who the collectors are in your area. A veritable unending supply of curios may exist in the attic of one of your library patrons. Since nearly everyone collects something, it's only a matter of finding them. Often, one collector leads you to another.

Plan a year of displays at a time by choosing a general theme to work around. You can always deviate from it if something more interesting pops up.

Make regular trips to hobby shops, gift shops, and dime stores just to look for display items. Go ahead and buy the items that catch your eye; plan a use later.

Keep your materials and supplies organized and in an accessible place. A quick glance through the boxes and shelves will tell you whether or not

Anne Sanders is Director of the East Albemarle Regional Library in Elizabeth City, North Carolina. you need to buy something new for your next display.

Plan around books. I use the displays primarily to promote books on a particular subject. Check first to make sure there are enough books on the shelves to complete your display. If you plan ahead, you can borrow through interlibrary loan the books you lack in your library.

\section{Materials for Display}

This list will grow with almost every display. So far, I found the following items useful.

Fabric: This has been essential to nine out of ten of the displays I have done. To date, I have accumulated about fifteen different colors and kinds of fabrics from burlap and felt to taffeta and velvet. This material is usually draped loosely on the shelf. It provides color and softness for the display.

Gift Wrap Paper: For a base, for cutouts, and for backdrops, this is attractive and useful. Just look at the variety available, and for less than a dollar, you have a versatile item to work with.

Other Paper Goods: Paper napkins, cups, plates, and placemats change design from year to year. You only have to browse, look, and imagine what you can do with them. Doilies are useful for a Valentine motif, of course, but can also be cut into snowflakes or used for lace collars and cuffs.

Boxes and Cans: Positioned under a drape, boxes and cans of assorted shapes and sizes are useful for stands. A display on more than one level is sometimes necessary.

Cake Decorations: I happened on these as I was looking for something else and have been adding several a year to my collection. So far, the collection includes a hunter, a fisherman, a tennis player, a jogger, a skier, dancers, basketball and football players, a surfer, a witch, a skateboarder, a ship captain, a golfer, and, of course, a bride and groom. I use them in a variety of ways with other miniature props for seasonal displays. Children love them.

Natural Objects: Pine cones, leaves, straw, vegetables, fruit, seashells - all make attractive fill-ins. I use sand a lot in the summer but always 
put it in shallow boxes lined with aqua terry cloth to make cleaning up easy.

Items From Home: I used just about every figurine, dish, placemat, and other portable object I own. Not only does it save money, it saves storage space at the library.

Baskets: For holding books or a Thanksgiving harvest, baskets are great. Keep your eye out for sales and get four just alike.

Artificial Objects: Plastic fruit, vegetables, flowers, and foliage are all versatile, durable, and easy to store.

Miniatures: Make your own little presents to put under a little Christmas tree. Buy any tiny object, such as a woodstove, when you come across one. I shop at a local flea market for my miniatures.

Imitation Turf: This is good for a putting green, football field, or meadow. It's expensive but will last until you retire. You need only four twelveinch squares.

Jigsaw Puzzles: One of the United States and one of your state can be used with travel and local history themes. If you can't find a puzzle, a roadmap will do.

Little Sign Holders: Make your own or buy some from a library supplier. Always caption your displays; you may think your theme is obvious, but the display will be wasted if you don't make your message clear. Save the covers from catalogs. The stiff white paper on the inside is good for signs and holders.

Book Supports: Use metal bookends or some other device to support the books that you want to stand upright.

Ribbons: I use the wide ones for borders and the narrow ones for little bows which can be used in many ways.

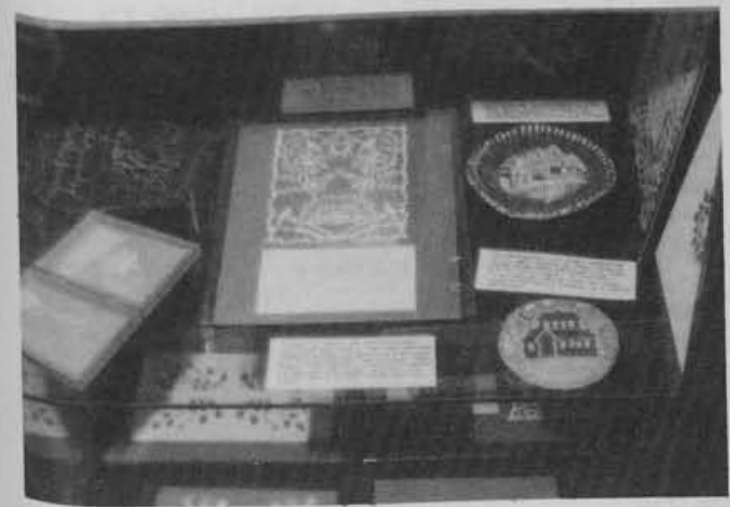

A display on Scherenschnitte, the art of paper cutting, shows how the work of a local craftsman can be used in an attractive exhibit.

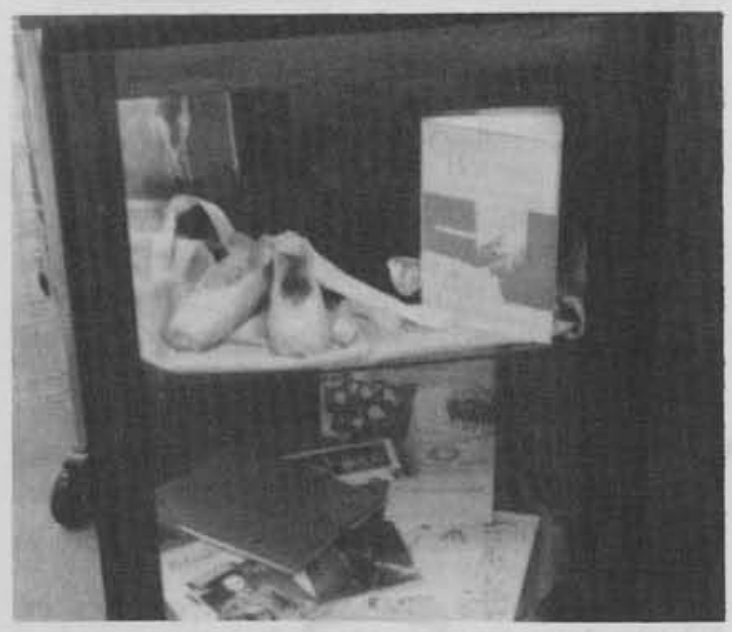

Ballet shoes autographed by Patricia McBride form the focal point of a display on dance.

Linens: Hand-worked placemats, luncheon cloths, and napkins make good display devices for cookbooks and other home-oriented themes.

School-Related Items: Notebooks, pennants, and even football helmets from area schools are good for all-year decorator items in YA areas. For back-to-school themes, add artificial apples and small slates.

Greeting Cards: Save your Valentines, birthday cards, and all greeting cards. They can be cut out and pasted for posters.

Special Helps: These items are not cheap, but are worth the investment for the amateur. Lettering devices, kits with special pens, stencils, and adhesive tape can be used by anyone. Press-on or rub-on letters are attractive and easy to use. The only drawback is the expense, since vowels are used up before consonants, and a whole sheet must be purchased for the few letters you need. A calligraphy set is useful for anyone who is adept at freehand lettering. The effect is beautiful, but not everyone can do it. A stencil maker is expensive but ideal for the small library. Easy to use, small in size, and versatile, this machine (combined with a mimeograph machine) is only one step behind an offset press.

Photographs: Take a picture of every display and poster you make. These pictures are useful for many reasons and will portray one facet of the library's history.

\section{Posters}

Posters are my favorite things to make because of their possibilities. They can be small or large; one, two, or three dimensional; drawn on; 
pasted on; stapled on; and even sewn on. For the creative person, a blank piece of poster paper is a playground, where scraps of material, magic markers, and rickrack can be used for interesting effects.

Go through junk mail for pictures and captions to paste onto a colored background. This is the easiest kind of poster to make, but it can be effective when used with a quotation or "catchy" caption.

Use fabric, fake fur, rickrack, buttons, glitter, fringe, doilies, felt, fake eyes, yarn, rope, ribbon. leaves, and other lightweight items for hair, borders, and outlines. These are especially helpful for the person who can't draw.

Study greeting cards, ads, and commercial displays for adaptable ideas. Despite your first impression, all of these are usually simple designs.

Use a lettering machine or some other kind of prepared letters unless you do good freehand printing.

Make a list of subject areas on the back of each poster to suggest books to accompany the poster. Have each branch listed on the back so that the posters can circulate to all bookmobiles and branch libraries.

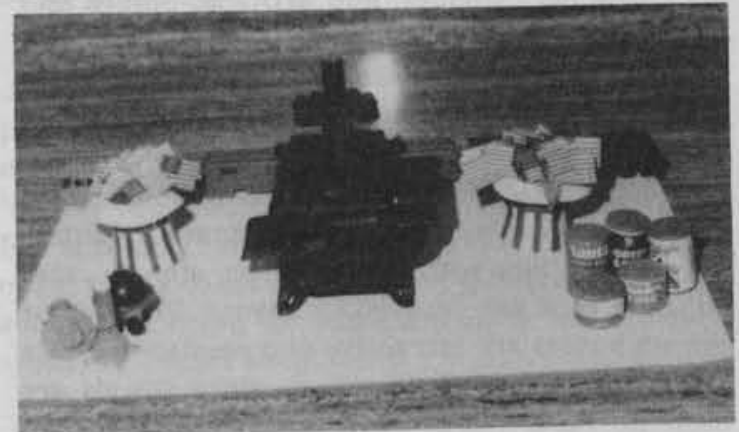

"Buy any tiny object, such as a woodstove, when you come across one."

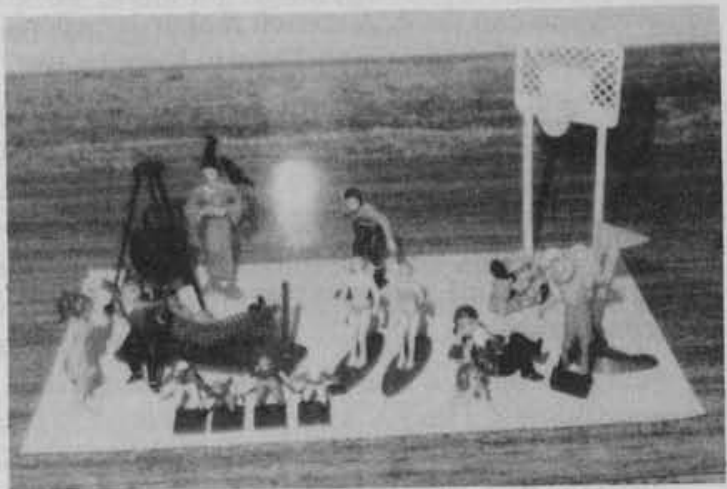

Cake decorations can be used in a variety of ways for seasonal displays.
Cut poster paper in half for most displays in order to economize. My theory is that it is better to spend a little time and money on a lot of posters than a lot of time and money on one poster.

Display posters on easels rather than thumbtacking them on a wall or bulletin board. This makes them more visible.

Keep posters simple. Curb your desire to fill up every inch and put in only essential information.

In conclusion, there is a vast supply of ideas "out there," but you have to be on the lookout for them. For example, a local craftsman's fair is one place to solicit interesting items for display. Most of the participants will be flattered to be invited to exhibit their wares. Likewise, while in a dress shop recently, I overheard a customer mention that she had a large hat collection. I immediately asked her if she would consider displaying some of them; she agreed. Another instance involved a friend of mine whose daughter is a professional ballerina. When the library recently acquired a number of books on dance, I borrowed a tutu, a pair of worn ballet shoes autographed by Patricia McBride, and some dance programs from her for the display.

After thirteen years of creating displays, postters, and other promotional items, I naturally feel threatened at times by burnout. When that happens, I get up, go out, and make my rounds. Something always turns up.

APPENDIX 1

Themes I Have Used

Collections from patrons

antique bottles

handmade lace and other fancy needlework

bargello and needlepoint

antique dolls

antique Christmas cards

antique toys

banks

memorabilia and souvenirs of the Royal Family

thermometers

fans

frog statues

cupid statues

seashells

sheet music

elephant

pigs

Victorian jewelry

old kitchen utensils

Depression glass

paperweights

old valentines

tin soldiers

egg craft

decoys

old children's books

stained glass 
Other

futurism

consumerism

heraldry

gardening

romance

inspirational books

health and beauty

cookbooks

birds

travel

all sports in season: hunting, golf, basketball

hobbies

all popular holidays

boating

current events

money management

do-it-yourself

past best sellers

animals

dancing

art

preserving and canning

school aids

banned books

Egyptology

Foreign Language Center

Ireland

investments

children's books from around the world

winterizing your home

fishing and boating

personal grooming and hygiene

old age

weddings

ways to earn money at home

ballet

local crafts

North Carolina books

self-help

back to school

child-rearing

\section{Selected Bibliography}

Chase's Calendar of Annual Events. Flint, Mich.: Apple Tree Press, 1983.

Coplan, Kate. Effective Library Exhibits. 2d ed, Dobbs Ferry, N.Y.: Oceana, 1974.

Edsall, Marian S. Library Promotion Handbook. Phoenix: Oryx, 1980.

Garvey, Mona. Library Displays. New York: H.W. Wilson, 1969.

Library of Clip Art. Bloomfield, N.J.: Library Educational Institute, 1978

Rice, Betty. Public Relations for Public Libraries. New York: H.W. Wilson, 1972.

Sherman, Steve, $A B C$ 's of Library Promotion. Metuchen, N.J.: Scarecrow, 1971.

Wallick, Clair H. Looking for Ideas? Metuchen, J.J.: Scarecrow, 1970.

\section{REGIONAL \\ LOCAL HISTORY GENEALOGY}

PUBLISHERS and BOOKSELLERS of reprints and originals ... Regional and County History, Genealogical source material, Colonial Americana, Revolutionary and Civil War material ... Primary emphasis on Southeastern states ... Publications of the South Carolina Historical Society and North Carolina Genealogical Society. Write for complete catalogue.

Thomas E. Smith Publisher

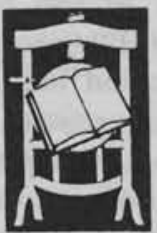

THE REPRINT COMPANY, PUBLISHERS

Post Office Box 5401

Spartanburg, S.C. 29304
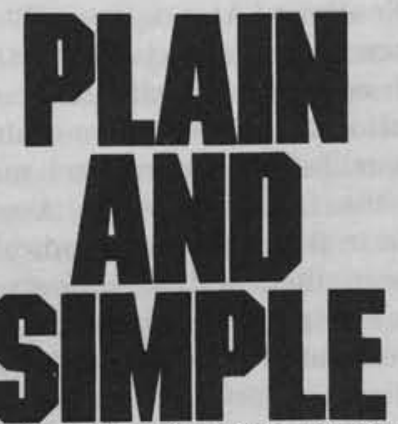

Our physical size and financial strength-necessary to make and honor commitments-indicate the successful working relationships we have with thousands of libraries worldwide.

But the plain truth is, simply, that it is our sensitivity to your unique requirements, and our flexibility in providing an exhaustive and relentless effort for total customer service that is our real strength.

We want to work with you-to help you provide exceptional patron service, which is your strength.

We can help. Write today-

\section{EBSCO SURSCRIPTION SERVICES The Serials Professional}

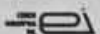

8000 Forbes Place, Suite 204

Springfield. VA 22151

(703) $321.7494 / 321.9630$ 